DOI: https://doi.org/10.24297/jac.v16i0.8264

\title{
Synthesis, Spectral Characterization, Thermal and In vitro Antimicrobial Studies for Novel Co(II) and $\mathrm{Ni}(\mathrm{II})$ Complexes of ( $\mathrm{N}, \mathrm{N}^{\prime}$-(1,2-Phenylene)Bis(2-Aminobenzamide).
}

\author{
Hanaa A. El-Boraey ${ }^{\text {a }}$, Azza A. Serag El-Din ${ }^{\text {b }}$, Ahmed A. Sakr ${ }^{\text {. }}$. \\ a Department of Chemistry, Faculty of Science, Menoufia University, Shebin El- Kom, Egypt. \\ ${ }^{b}$ Department of Chemistry, The Regional Institute Joint of Medical and Chemical Analysis, Ministry of Health, \\ Shebin El-Kom, Egypt. \\ c Department of Chemistry, Faculty of Science, Menoufia University, Shebin El- Kom, Egypt. \\ helboraey@yahoo.com, azzatarek1965@hotmail.com, a_sakr210@yahoo.com.
}

\begin{abstract}
Novel metal complexes of $\mathrm{Co}(\mathrm{II})$ and $\mathrm{Ni}(\mathrm{II})$ have been prepared from reaction of their different salts with previously prepared ligand (L) namely ( $\mathrm{N}_{1} \mathrm{~N}^{\prime}-(1,2$-phenylene)bis(2-aminobenzamide). Synthesis ligand and its metal (II) complexes (1-5) were reported and characterized with the help of analytical and physiochemical analysis as elemental, IR spectra, thermal (TG/DTG), UV-Vis, magnetic susceptibility and molar conductance in $\mathrm{DMF}$, On the view of the previous data and measurements, the structure and composition species behave as mononuclear and octahedral geometry has been proposed for all the complexes except for complex (1) adopted tetrahedral structure. Furthermore, the in vitro antibacterial Staphylococcus aureus (ATCC 25923) as Grampositive strain, Escherichia coli (ATCC 25922) as Gram-negative strain and antifungal Candida albicans (ATCC 10231) have been studied for all samples using disc diffusion method against Ampicillin and Fluconazole as positive controls, respectively. The results show that complexation facilitates the activity of most studied metal complexes than the free ligand.
\end{abstract}

Key words: Synthesis; Spectral; Thermal Studies; Metal Complexes; Antibacterial; Antifungal Activity.

\section{Introduction}

During the last several years, coordination chemistry has been considerably enriched due to the synthesis and characterization of a large number ligands and their transition metal complexes in which the metal is coordinated by sulfur, nitrogen and oxygen [1,2]. Coordination chemistry of transition metal complexes has been the subject of interest, because of the complexities associated with many variable factors as oxidation states, variety of geometries around the metal ions, donating properties of ligands and their influence on spectral, catalytic and biological properties of metal ions [3-7]. The interest in nitrogen ligands has increased over the last few years because of the promising results and present several advantages, they are largely available in enantiomerically pure form, both in the chiral pool and as cheap industrial chemical intermediates [6, 8-10]. Transition metal complexes introduce large and wide spectrum of biological, enantioselective catalytic and therapeutic activity. Also many metal complexes were used as antimicrobial, antitumor and antifungal agents [2]. The success of such metal complexes for enantioselective catalysis is largely dependent on the structure and electronic properties of the chiral ligands [11]. Many compounds containing amino groups were also used as analytical reagents for the separation and determination of some transition metal ions [12]. Most metal complexes have a variety of applications including biological, clinical and analytical $[13,14]$. Some drugs showed increased activity when used as metal chelates rather than as organic compounds [15]. Metals like nickel, copper, cobalt and manganese have high ability for coordination because of their smaller size and higher nuclear charge [16]. In the view of interest and importance of these ligands, Herein we reported the synthesis of novel metal complexes of $\mathrm{Co}(\mathrm{II})$ and $\mathrm{Ni}(\mathrm{II})$ by reaction of their different salts with (N,N'-(1,2-phenylene)bis(2aminobenzamide). The ligand and its complexes have been characterized with the help of analytical, spectral 
characterization, and thermal techniques. Also, the current compounds were assayed by the disc diffusion method for antibacterial activity against (Staphylococcus aureus ATTCC 25923), as Gram-positive strain, (Escherichia coli ATTCC 25922), as Gram-negative strain and antifungal (Candida albicansATCC 10231) using Ampicillin and Fluconazole as positive controls, respectively.

\section{Materials and Methods}

\subsection{Reagents and Physical Instruments}

All chemical, starting materials as well as solvents were purchased from (E.Merck) and used without further purification. The elemental analysis $(\mathrm{C}, \mathrm{H}, \mathrm{N})$ achieved at Cairo University, Micro analytical center, using CHNS932 (LECO) Vario Elemental Analyzer. Metal and halide ions of metal complexes were determined using the standard methods[17, 18]. The infrared spectra of ligand and its complexes were obtained using NenexeusNicolidite-640-MSA FT-IR spectrophotometer (4000-400 $\left.\mathrm{cm}^{-1}\right)$, Thermo-Electronics Co in $\mathrm{KBr}$ discs. In addition, the UV-Visible absorption spectra were measured in ethanol solvent using $4802 \mathrm{UV} / \mathrm{Vis}$ double beam spectrophotometer. The molar conductivities of studied complexes were estimated in DMF $\left(10^{-3} \mathrm{M}\right)$ using a CON 6000 conductivity meter. At room temperature, magnetic susceptibility of studied complexes were measured by the modified Gouy method using magnetic susceptibility Johnson Matthey balance. The effective magnetic moments were calculated using the formula $\mu_{\text {eff }}=2.828\left(\chi_{m} T\right)^{1 / 2}$ B.M., where $\chi_{m}$ is the molar susceptibility corrected for diamagnetism of all tomes in the compounds. Thermal analyses (TGA/DTG) were carried out by using a Shimadzu DTG/TG-50 thermal Analyzer with heating rate $10^{\circ} \mathrm{C} / \mathrm{min}$ in nitrogen atmosphere with a flowing rate $20 \mathrm{ml} / \mathrm{min}$ in the temperature range $28-1000{ }^{\circ} \mathrm{C}$ using platinum crucibles.

\subsection{Synthesis of Ligand}

The ligand was synthesized as reported for similar compounds previously [19]. A mixture of $2 \mathrm{H}$ benzo[d][1,3]oxazine-2,4(1H)-Dione, $(9.19 \mathrm{mmol}, 1.5 \mathrm{~g})$ and orthophenylene diamine, $(4.6 \mathrm{mmol}, 0.5 \mathrm{~g})$ react as 2:1 ratio, respectively in distilled water with continuous stirring at $60^{\circ} \mathrm{C}$ for about $3 \mathrm{~h}$. Heating on water bath was continued until the effervescence of $\mathrm{CO}_{2}$ gas ceased. The reaction mixture allowed standing for overnight. The formed precipitate with brown color collected by filtration then washed several times by distilled water and dried in vacuum. Recrystallization from methanol gave brown crystals of the ligand (L) $N_{,} N^{\prime}-(1,2-$ phenylene)bis(2-aminobenzamide). Yield: $73 \%$, Melting point $=157-160{ }^{\circ} \mathrm{C}$.

\subsection{Synthesis of Metal Complexes}

All complexes were synthesized using the following general procedure. To $20 \mathrm{ml}$ solution of prepared ligand (L), solution of different hydrated salts of $\mathrm{Co}(\mathrm{II})$ and $\mathrm{Ni}(\mathrm{II})$ were added with molar ratio 1:1 (M:L) using acetone and ethanol as solvent for synthesis of complexes $(\mathbf{1}, \mathbf{3}, \mathbf{4 , 5})$ and $(\mathbf{2})$, respectively. The reaction mixtures heated with reflux for 8-12 $\mathrm{h}$. The solid products removed by filtration with washing several times by the solvent followed by drying over $\mathrm{P}_{2} \mathrm{O}_{5}$.

\subsection{In Vitro Antimicrobial Studies:}

Antimicrobial activity of ligand (L) and its complexes were determined using a modified Kirby-Bauer disc diffusion method [20]. Disc diffusion method for bacteria and fungi tested by using approved standard methods developed by National Committee for Clinical Laboratory Standards (NCCLS) [21]. Agar disc plate using agar medium was used to study the activity of synthesized compounds with Ampicillin and Fluconazole as reference drugs for bacteria and fungi, respectively. The ligand (L) and its complexes were examined against Staphylococcus aureus (ATTCC 25923) as Gram-positive strain, Escherichia coli (ATTCC 25922) as Gram-negative strain and Candida albicans (ATCC 10231) as fungi. The strains were provided by Microbiology Department, Faculty of Pharmacy, Misr University for Science and Technology, $6^{\text {th }}$ of October City, Giza, Egypt. The activity of tested samples was studied at different concentration of 10 and $20 \mathrm{mg} / \mathrm{mL}$ in DMF solvent. Discs of $6 \mathrm{~mm}$ were impregnated with the samples solution and allowed to dry at room temperature, testing was performed on 
nutrient and sabered dextrorse agar for antibacterial and antifungal strains, respectively. For each strain plates were inoculated by dipping two sterile cotton swabs into $0.5 \mathrm{McF}$ arland (approximately $10^{4}-10^{6}$ colony forming unit (CFU/ml) suspension of the used microorganisms and streaking the plate surface in three directions. After the plate was allowed to dry for $20 \mathrm{~min}$, The petri dishes were subsequently incubated at $35-37^{\circ} \mathrm{C}$ and $30^{\circ} \mathrm{C}$ about 24-48 h for (Gram- positive, Gram- negative) bacteria and fungi, respectively. Standard discs of Ampicillin (antibacterial agent) and Fluconazole (antifungal agent) [22] were used as positive controls for antimicrobial activity but the filter paper disc impregnated in DMF was used as negative control. The diameter of the inhibition zones was measured in millimeters as a criterion for activity of studied compounds.

\section{Results and Discussion}

\subsection{Characterization of Ligand and Metal Complexes}

\subsubsection{Physical Properties}

The ligand (L) and its complexes are colored solid powder, stable towards air and partially soluble in some alcohols, insoluble in most common organic solvents but freely soluble in DMF and DMSO. At room temperature, the molar conductivity of complexes achieved in DMF solution $\left(10^{-3} \mathrm{M}\right)$. The low values of molar conductivity of complexes ascribed to the absence of any ions rather than ionic association to the metal ions during complex formation indicating that the complexes are non- electrolytes in nature except complex (4) is (1:2) electrolyte [23-25]. The analytical data of the complexes suggest that the metal to ligand ratio is (1L:1M) for all complexes ( Table 1).

\subsubsection{FT-IR Spectra with the Mode of Bonding}

The bonding modes of the ligand were elucidated by comparing IR spectra of the ligand and its metal complexes. The IR spectral absorptions are listed in table 2. The fundamental IR spectral bands of the four nitrogen ligand including both two amide and two amine groups have been discussed previously [26]. Generally, the IR spectra of the complexes exhibit broadened and merged peaks when compared by the sharp peaks of the ligand only. The ligand shows broad bands at 3463 and $3370 \mathrm{~cm}^{-1}$ assigned to stretching vibration $\mathrm{u}(\mathrm{NH})$ of amine groups. Also the spectrum of ligand exhibits bands at 1652, 1520, 1299, and $745 \mathrm{~cm}^{-1}$ due to stretching vibrations of amide I, amide II, amide III and amide IV groups, respectively. On complexation, the stretching vibration of $\mathrm{u}(\mathrm{NH})$ amine group was shifted towards low frequencies in all metal complexes indicating that the coordination mode is through the $\mathrm{NH}_{2}$ amine groups $[3,6,14,27-29]$. The amide I, amide II, amide III, and amide IV bands in metal complexes appear at 1640-1584, 1511-1485, 1295-1281, and 756-744 cm${ }^{-1}$, respectively[30, 31]. The high intensity and strong broad band related to the $\mathrm{v}(\mathrm{OH})$ vibrations of the hydrated water molecules or coordinated hydroxyl groups appear clear band and in many times hiding and unites with the $\mathrm{v}(\mathrm{NH})$ stretching vibrations which appear in the same region of the $v(\mathrm{NH})$ amine and $v(\mathrm{OH})[14,29]$. By another way for confirming the mode of coordination, the appearance of new peaks at $528-512 \mathrm{~cm}^{-1}$ and $480-420 \mathrm{~cm}^{-1} \mathrm{due}$ to $v(M-O)$ and $u(M-N)$, respectively [29, 30, 32]. The acetato complexes show bands at (1584-1580), and (13871380 ) for the $\mathrm{v}_{\text {asym }}\left(\mathrm{COO}^{-}\right)$and $\mathrm{v}_{\text {sym }}\left(\mathrm{COO}^{-}\right)$respectively (Table 2$)$, The difference of $197 \mathrm{~cm}^{-1}$ give no doubt for the monodentate nature of the acetate [30]. It necessary to notice that the region of $\mathrm{U}_{\text {asym }}\left(\mathrm{COO}^{-}\right)$overlapped with amide $\mathrm{I} \mathrm{U}(\mathrm{C}=\mathrm{O})$ in some metal complexes $[3,14]$. 


\begin{tabular}{|c|c|c|c|c|c|c|c|c|c|c|}
\hline \multirow[t]{2}{*}{ No. } & \multirow{2}{*}{$\begin{array}{l}\text { Compound/ } \\
\text { color }\end{array}$} & \multirow{2}{*}{$\begin{array}{l}\text { Empirical } \\
\text { formula }\end{array}$} & \multirow{2}{*}{$\begin{array}{c}\text { Yield } \\
\text { (\%) }\end{array}$} & \multirow{2}{*}{$\begin{array}{l}\text { Decop. } \\
\text { T. } /{ }^{\circ} \mathrm{C}\end{array}$} & \multicolumn{5}{|c|}{ Elemental Analysis. Calc. (F) (\%) } & \multirow[t]{2}{*}{$\left(\Lambda_{\mathrm{m}}\right)^{c}$} \\
\hline & & & & & C & $\mathrm{H}$ & $\mathrm{N}$ & Metal & $\mathrm{Cl}$ & \\
\hline L & Brown & $\mathrm{C}_{20} \mathrm{H}_{18} \mathrm{~N}_{4} \mathrm{O}_{2}$ & 73 & 157 & $69.40(71.08)$ & $05.20(04.72)$ & $16.18(16.09)$ & …….... & ........... & \\
\hline 1 & $\begin{array}{c}{[\mathrm{Co}(\mathrm{L}) \mathrm{Cl}(\mathrm{OH})]^{x}} \\
\text { Green }\end{array}$ & $\mathrm{C}_{20} \mathrm{H}_{19} \mathrm{~N}_{4} \mathrm{O}_{3} \mathrm{CoCl}$ & 58 & 215 & $52.59(53.80)$ & $4.15(04.72)$ & $12.24(11.22)$ & $12.00(11.89)$ & $7.75(7.44)$ & 32 \\
\hline 2 & $\begin{array}{l}{\left[\mathrm{Co}(\mathrm{L})\left(\mathrm{Cl}_{2}\right)\left(\mathrm{H}_{2} \mathrm{O}\right)_{2}\right]^{y}} \\
\text { Violet }\end{array}$ & $\mathrm{C}_{20} \mathrm{H}_{22} \mathrm{~N}_{4} \mathrm{O}_{4} \mathrm{CoCl}_{2}$ & 50 & 225 & $46.88(45.70)$ & $04.29(03.26)$ & $10.95(12.00)$ & $11.50(11.76)$ & $13.86(13.44)$ & 37 \\
\hline 3 & $\begin{array}{c}{\left[\mathrm{Co}(\mathrm{L})\left(\mathrm{H}_{2} \mathrm{O}\right)_{2}(\mathrm{OH})(\mathrm{OAc})\right] .6 \mathrm{H}_{2} \mathrm{O}} \\
\text { Brownish yellow }\end{array}$ & $\mathrm{C}_{22} \mathrm{H}_{38} \mathrm{~N}_{4} \mathrm{O}_{13} \mathrm{Co}$ & 75 & 190 & $42.24(42.50)$ & $5.76(04.36)$ & $8.96(08.56)$ & $9.42(8.5)$ & ------ & 8 \\
\hline 4 & $\begin{array}{c}{\left[\mathrm{Ni}(\mathrm{L})\left(\mathrm{H}_{2} \mathrm{O}\right)_{4}\right] \mathrm{Cl}_{2} \cdot 2 \mathrm{H}_{2} \mathrm{O}} \\
\text { Buff yellow }\end{array}$ & $\mathrm{C}_{20} \mathrm{H}_{30} \mathrm{~N}_{4} \mathrm{O}_{8} \mathrm{NiCl}_{2}$ & 84 & 230 & $41.11(40.77)$ & $5.1(03.63)$ & $9.59(09.39)$ & $10.05(9.89)$ & $12.16(11.86)$ & 100 \\
\hline 5 & $\begin{array}{c}{\left[\mathrm{Ni}(\mathrm{L})\left(\mathrm{H}_{2} \mathrm{O}\right)_{2}(\mathrm{OH})(\mathrm{OAc})\right] \cdot 2 \mathrm{H}_{2} \mathrm{O}} \\
\text { Pale yellow }\end{array}$ & $\mathrm{C}_{22} \mathrm{H}_{30} \mathrm{~N}_{4} \mathrm{O}_{9} \mathrm{Ni}$ & 85 & 225 & $47.76(47.75)$ & $5.42(04.40)$ & $10.13(08.57)$ & $10.61(9.34)$ & ------- & 15 \\
\hline
\end{tabular}

${ }^{*} \mathrm{x}$; Synthesis with acetone as solvent; Synthesis with ethanol as solvent, c; Conductance $\Omega^{-1} \mathrm{~cm}^{2} \mathrm{~mol}^{-}$ ${ }^{1}$ DMF $\left(10^{-3} \mathrm{M}\right)$.

Table 1: Analytical and physical data for the ligand and its metal complexes.

\begin{tabular}{|c|c|c|c|c|c|c|}
\hline No & Compound & $(\mathrm{O}-\mathrm{H}),(\mathrm{NH} 2)$ & $\mathrm{U}(\mathrm{N}-\mathrm{H})$ & $v(M-O)$ & $\mathrm{u}(\mathrm{M}-\mathrm{N})$ & $\mathrm{u}(\mathrm{COO})$ \\
\hline & Ligand $\left(\mathrm{C}_{20} \mathrm{H}_{18} \mathrm{~N}_{4} \mathrm{O}_{2}\right)$ & $3463,3370(\mathrm{~m})$ & $1600(\mathrm{~m})$ & - & - & - \\
\hline 1 & {$[\mathrm{Co}(\mathrm{L}) \mathrm{Cl}(\mathrm{OH})]^{x}$} & $3425(\mathrm{~s})$ & $1590(\mathrm{sh})$ & $557(m)$ & $420(\mathrm{sh})$ & - \\
\hline 2 & {$\left[\mathrm{Co}(\mathrm{L})\left(\mathrm{Cl}_{2}\right)\left(\mathrm{H}_{2} \mathrm{O}\right)_{2}\right]^{\mathrm{y}}$} & $3428(m), 3299(m)$ & 1572(m) & $513(m)$ & 480(sh) & - \\
\hline 3 & {$\left[\mathrm{Co}(\mathrm{L})\left(\mathrm{H}_{2} \mathrm{O}\right)_{2}(\mathrm{OH})(\mathrm{OAc})\right] 6 \mathrm{H}_{2} \mathrm{O}$} & $3353(\mathrm{~m})$ & 1584(s) & $528(m)$ & 480(sh) & 1584(s), 1380(sh) \\
\hline 4 & {$\left[\mathrm{Ni}(\mathrm{L})\left(\mathrm{H}_{2} \mathrm{O}\right)_{4}\right] \mathrm{Cl}_{2} \cdot 2 \mathrm{H}_{2} \mathrm{O}$} & $3419(\mathrm{~s}), 3320(\mathrm{sh})$ & $1575(w)$ & $512(m)$ & 420(sh) & \\
\hline 5 & {$\left[\mathrm{Ni}(\mathrm{L})\left(\mathrm{H}_{2} \mathrm{O}\right)_{2}(\mathrm{OH})(\mathrm{OAc})\right] 2 \mathrm{H}_{2} \mathrm{O}$} & $3428(\mathrm{~m}), 3320(\mathrm{sh})$ & 1580(s) & $527(\mathrm{~m})$ & 420(sh) & $1580(\mathrm{~s}), 1387(w)$ \\
\hline
\end{tabular}

*sh. shoulder; s, strong; m, medium; w, week; $v$. Stretching; $x$, synthesis with acetone as solvent; $y$, synthesis with ethanol as solvent

Table 2: Fundamental IR spectral bands $\left(\mathrm{cm}^{-1}\right)$ of ligand and its complexes. 


\subsubsection{Electronic Spectra and Magnetic Measurements}

The nature of the ligand and its metal complexes (1-5) have been discussed from the electronic absorption spectral data $\left(\lambda_{\max }, \mathrm{nm}\right)$, and room temperature effective magnetic moment values, as they are essential for predicting and establishing their stereochemistry (Table 3). The ligand and its complexes show the high energy bands in the range of (240-250), (340-360) nm due to $\pi \rightarrow \pi^{*}, n \rightarrow \pi^{*}$ transitions related to benzene and/ or other chromophore and (410-460 $\mathrm{nm}$ ) assigned to ligand to metal charge transfer (LMCT) transitions, respectively.

\subsubsection{Cobalt (II)Chelates}

The electronic spectrum of complex $[\mathrm{Co}(\mathrm{L}) \mathrm{Cl}(\mathrm{OH})](\mathbf{1})$ displays one broad band at $660 \mathrm{~nm}$ in visible region due to ${ }^{4} \mathrm{~A}_{2}(\mathrm{~F}) \rightarrow{ }^{4} \mathrm{~T}_{1}(\mathrm{P})$ transition. The measured magnetic moment at room temperature is $4.7 \mathrm{BM}$. The presence of spectral band and magnetic moment are consistent with those expected for tetrahedral coordinate [27, 33].Moreover, the electronic absorption spectra of Co(II) complexes (2) and (3) display $d$-d transition bands at $(650,550)$ and $(550) \mathrm{nm}$ assigned to ${ }^{4} \mathrm{~A}_{2 g}(\mathrm{~F}) \rightarrow{ }^{4} \mathrm{~T}_{1(\mathrm{P})},{ }^{4} \mathrm{~T}_{1 \mathrm{~g}}(\mathrm{~F}) \rightarrow{ }^{4} \mathrm{~A}_{2 g}(\mathrm{~F})$ and ${ }^{4} \mathrm{~T}_{1 \mathrm{~g}}(\mathrm{~F}) \rightarrow{ }^{4} \mathrm{~A}_{2 g}(\mathrm{~F})$, respectively, suggesting an octahedral geometry around Co (II) ion for both complexes [6, 27, 34-38]. The magnetic moment values of complexes $(\mathbf{2}, \mathbf{3})$ are within the reported range of 4.8-5.6 BM (Table 3). These observations together give adequate support to high spin octahedral environment around the Co(II) ions [3, 27, 28, 35-37].

\subsubsection{Nickel(II) chelates}

The electronic absorption spectra of nickel(II) complexes $\left[\mathrm{Ni}(\mathrm{L})\left(\mathrm{H}_{2} \mathrm{O}\right)_{4}\right] \cdot \mathrm{Cl}_{2} \cdot 2 \mathrm{H}_{2} \mathrm{O} \quad$ (4) and $\left[\mathrm{Ni}(\mathrm{L})(\mathrm{OH})\left(\mathrm{H}_{2} \mathrm{O}\right)_{2}(\mathrm{OAC})\right] .2 \mathrm{H}_{2} \mathrm{O}(5)$ display d-d transition bands at around $(640,760)$ and $(550,645) \mathrm{nm}$ attributed to ${ }^{3} A_{2 g}(F) \rightarrow{ }^{3} T_{1 g}(F)$ and ${ }^{3} A_{2 g}(F) \rightarrow{ }^{3} T_{1 g}(P)$, respectively. These bands confirm the octahedral structure geometry for two complexes $[14,36]$. The room temperature magnetic moment of both complexes exists in (2.6-2.95 BM) range, related to two unpaired electrons in an octahedral geometry $[3,14,28,39]$.

\begin{tabular}{|c|c|c|c|c|}
\hline \multirow[t]{2}{*}{ No. } & \multirow[t]{2}{*}{ Compound } & \multicolumn{2}{|l|}{$\lambda_{\max }(\mathrm{nm})$} & \multirow[t]{2}{*}{$\mu_{\text {eff }}(B . M)$} \\
\hline & & (d-d) Transition & Intra-Ligand and transfer bands & \\
\hline L & $\mathrm{L}\left(\mathrm{C}_{20} \mathrm{H}_{18} \mathrm{~N}_{4} \mathrm{O}_{2}\right)$ & - & $240,340,420,460$ & - \\
\hline 1 & {$[\mathrm{Co}(\mathrm{L}) \mathrm{Cl}(\mathrm{OH})]^{\mathrm{x}}$} & 660 & $240,350,465$ & 4.7 \\
\hline 2 & {$\left[\mathrm{Co}(\mathrm{L})(\mathrm{Cl})_{2}\left(\mathrm{H}_{2} \mathrm{O}\right)_{2}\right]^{\mathrm{y}}$} & 550,650 & $245,340,440$ & 5.6 \\
\hline 3 & {$\left[\mathrm{Co}(\mathrm{L})\left(\mathrm{H}_{2} \mathrm{O}\right)_{2}(\mathrm{OH})(\mathrm{OAc})\right] 6 \mathrm{H}_{2} \mathrm{O}$} & 550 & $239,332,460$ & 5.2 \\
\hline 4 & {$\left[\mathrm{Ni}(\mathrm{L})\left(\mathrm{H}_{2} \mathrm{O}\right)_{4}\right] \mathrm{Cl}_{2} \cdot 2 \mathrm{H}_{2} \mathrm{O}$} & 640,760 & $240,340,460$ & 2.6 \\
\hline 5 & {$\left[\mathrm{Ni}(\mathrm{L})\left(\mathrm{H}_{2} \mathrm{O}\right)_{2}(\mathrm{OH})(\mathrm{OAc})\right] 2 \mathrm{H}_{2} \mathrm{O}$} & 550,645 & $250,340,460$ & 2.95 \\
\hline
\end{tabular}

${ }^{*} x$, synthesis with acetone as solvent; $y$, synthesis with ethanol as solvent.

Table 3: Electronic absorption spectra $\boldsymbol{\lambda}_{\max }(\mathrm{nm})$, room temperature effective magnetic moment values ( $\left.\boldsymbol{\mu}_{\text {eff }} B . M\right)$ of complexes. 


\subsubsection{Thermal Studies for Ligand and Its Complexes}

The content of a particular component in a complex changes with its composition and structure. Thus, the content of such components can be determined based on the mass losses of these components in the thermogravimetric plots of the complex [40,41]. Thermogravimetric analysis is a simple and more accurate technique for studying decomposition pattern and thermal stability. Thermal properties of ligand and its metal complexes were carried out by using thermogravimetry TG/DTG technique in the temperature range RT- 1000 ${ }^{\circ} \mathrm{C}$ under nitrogen atmosphere. The nature of proposed chemical change with temperature and the percent of residue for ligand and complexes (1-5) tabulated in Table 4. Obtained results were in agreement with the suggested theoretical formulae from elemental analysis $[14,28]$.

\subsubsection{Thermal Studies for Ligand}

The thermal behavior curve of the ligand shows three successive decomposition stages within the temperature range $157-800^{\circ} \mathrm{C}$ associated with endothermic DTG peaks at $265,330,570^{\circ} \mathrm{C}$ which corresponds to total mass loss of ligand (Calc. \%:100).

\subsubsection{Cobalt (II) Chelates}

The thermal behavior of $\mathrm{Co}(\mathrm{II})$ complexes $[\mathrm{Co}(\mathrm{L}) \mathrm{Cl}(\mathrm{OH})](\mathbf{1})$ and $\left[\mathrm{Co}(\mathrm{L})\left(\mathrm{H}_{2} \mathrm{O}\right)_{2} \mathrm{Cl}_{2}\right](\mathbf{2})$ are almost similar (Table 4). The TG/DTG curve of complexes (1) and (2) showed no weight loss up to $215^{\circ} \mathrm{C}$ and $225^{\circ} \mathrm{C}$, respectively, giving an indication that there is no water and/or any other adsorptive solvent molecules. The thermal decomposition of complexes (1) and (2) proceeds with three stages (Cal.\%87.0,84.72;F. 89.6,85.26) within the temperature range $215-750^{\circ} \mathrm{C}$ and $225-650^{\circ} \mathrm{C}$ associated with DTG peaks at $\left(250,440,575^{\circ} \mathrm{C}\right)$ and $\left(257,340,535^{\circ} \mathrm{C}\right)$, respectively. On the other hand, The thermal decomposition of complex (3) have different pathway, The TG/DTG curve exhibits weight lost regarded to the loss of three of the outside coordination sphere water molecules in range of $30-160^{\circ} \mathrm{C},\left(\mathrm{Cal}\right.$. \% 8.64; F. 8.88) associated with one DTG peaks at $60^{\circ} \mathrm{C}$. Cumulative decomposition may be associated to the release of other three water molecules at temperature range of $190-550^{\circ} \mathrm{C}$ (Cal. \% $79.28 ; \mathrm{F}$. 78.91) and DTG peaks at $260,340^{\circ} \mathrm{C}$. It notice that the decomposition stages for Co(II) complexes produce metal and metal oxide (CoO) as final residue for complexes (1) and (2,3), respectively (Fig. 1).

\begin{tabular}{|c|c|c|c|c|c|c|}
\hline \multirow{2}{*}{$\begin{array}{l}\mathrm{N} \\
\mathrm{O}\end{array}$} & \multirow[t]{2}{*}{ Compound } & \multicolumn{2}{|l|}{ Temp $/{ }^{\circ} \mathrm{C}$} & \multicolumn{2}{|c|}{ Mass. loss \% } & \multirow[t]{2}{*}{ Leaving species } \\
\hline & & DTG & TGA & Cal. & (F.) & \\
\hline \multirow[t]{2}{*}{1} & {$[\mathrm{Co}(\mathrm{L}) \mathrm{Cl}(\mathrm{OH})]^{\mathrm{x}}$} & $\begin{array}{l}250,440,57 \\
5\end{array}$ & $\begin{array}{l}215- \\
750\end{array}$ & 87.0 & (86.6) & Decomposition \\
\hline & & & $\begin{array}{l}\text { At } \\
750\end{array}$ & 13.0 & $(13.4)^{c}$ & $\equiv$ Co \\
\hline \multirow[t]{2}{*}{2} & {$\left[\mathrm{Co}(\mathrm{L})(\mathrm{Cl})_{2}\left(\mathrm{H}_{2} \mathrm{O}\right)_{2}\right]^{\mathrm{y}}$} & $\begin{array}{l}257,430,53 \\
5\end{array}$ & $\begin{array}{l}225- \\
650\end{array}$ & $\begin{array}{l}84.7 \\
2\end{array}$ & (85.26) & Decomposition \\
\hline & & & $\begin{array}{l}\text { At } \\
650\end{array}$ & $\begin{array}{l}15.2 \\
8\end{array}$ & $\begin{array}{l}(14.74) \\
c\end{array}$ & $\equiv \mathrm{CoO}$ \\
\hline \multirow[t]{3}{*}{3} & $\begin{array}{l}{\left[\mathrm{Co}(\mathrm{L})\left(\mathrm{H}_{2} \mathrm{O}\right)_{2}(\mathrm{OH})(\mathrm{OAc})\right] 6 \mathrm{H}_{2}} \\
\mathrm{O}\end{array}$ & 60 & $\begin{array}{l}30- \\
160\end{array}$ & 8.64 & (8.88) & $-3 \mathrm{H}_{2} \mathrm{O}$ \\
\hline & & 260,340 & $\begin{array}{l}190- \\
550\end{array}$ & $\begin{array}{l}79.2 \\
8\end{array}$ & (78.91) & $\begin{array}{l}3 \mathrm{H}_{2} \mathrm{O}+\text { Decompositio } \\
n\end{array}$ \\
\hline & & & $\begin{array}{l}\text { At } \\
550\end{array}$ & $\begin{array}{l}12.0 \\
8\end{array}$ & $\begin{array}{l}(12.21) \\
c\end{array}$ & $\equiv \mathrm{CoO}$ \\
\hline
\end{tabular}




\begin{tabular}{|lllllll|}
\hline 4 & {$\left[\mathrm{Ni}(\mathrm{L})\left(\mathrm{H}_{2} \mathrm{O}\right)_{4}\right] \mathrm{Cl}_{2} .2 \mathrm{H}_{2} \mathrm{O}$} & 70,138 & $30-$ & 6.16 & $(5.55)$ & $-2 \mathrm{H}_{2} \mathrm{O}$ \\
& & & 180 & & & \\
& & 305,589 & $230-$ & 74.8 & $(75.41)$ & Decomposition \\
& & 100 & 3 & & \\
& & & & & & \\
& & & At & 19.0 & $(19.04)$ & $\equiv \mathrm{NiO}+3 \mathrm{C}$ \\
& & & 100 & 1 & $c$ & \\
& & & 0 & & & \\
5 & {$\left[\mathrm{Ni}(\mathrm{L})\left(\mathrm{H}_{2} \mathrm{O}\right)_{2}(\mathrm{OH})(\mathrm{OAC})\right] 2 \mathrm{H}_{2}$} & 125 & $30-$ & 6.51 & $(6.54)$ & $-3 \mathrm{H}_{2} \mathrm{O}$ \\
& $\mathrm{O}$ & & 170 & & & \\
& & 300,371 & $225-$ & 79.9 & $(80.26)$ & Decomposition \\
& & & 650 & 9 & & \\
& & & At & 13.5 & $(13.20)$ & $\equiv \mathrm{NiO}$ \\
& & & 650 & & $c$ & \\
\hline
\end{tabular}

${ }^{*} \mathrm{X}$; synthesis with acetone as solvent; $y$, synthesis with ethanol as solvent; $C$, final product percent

Table 4: Thermal data of the complexes (1-5)
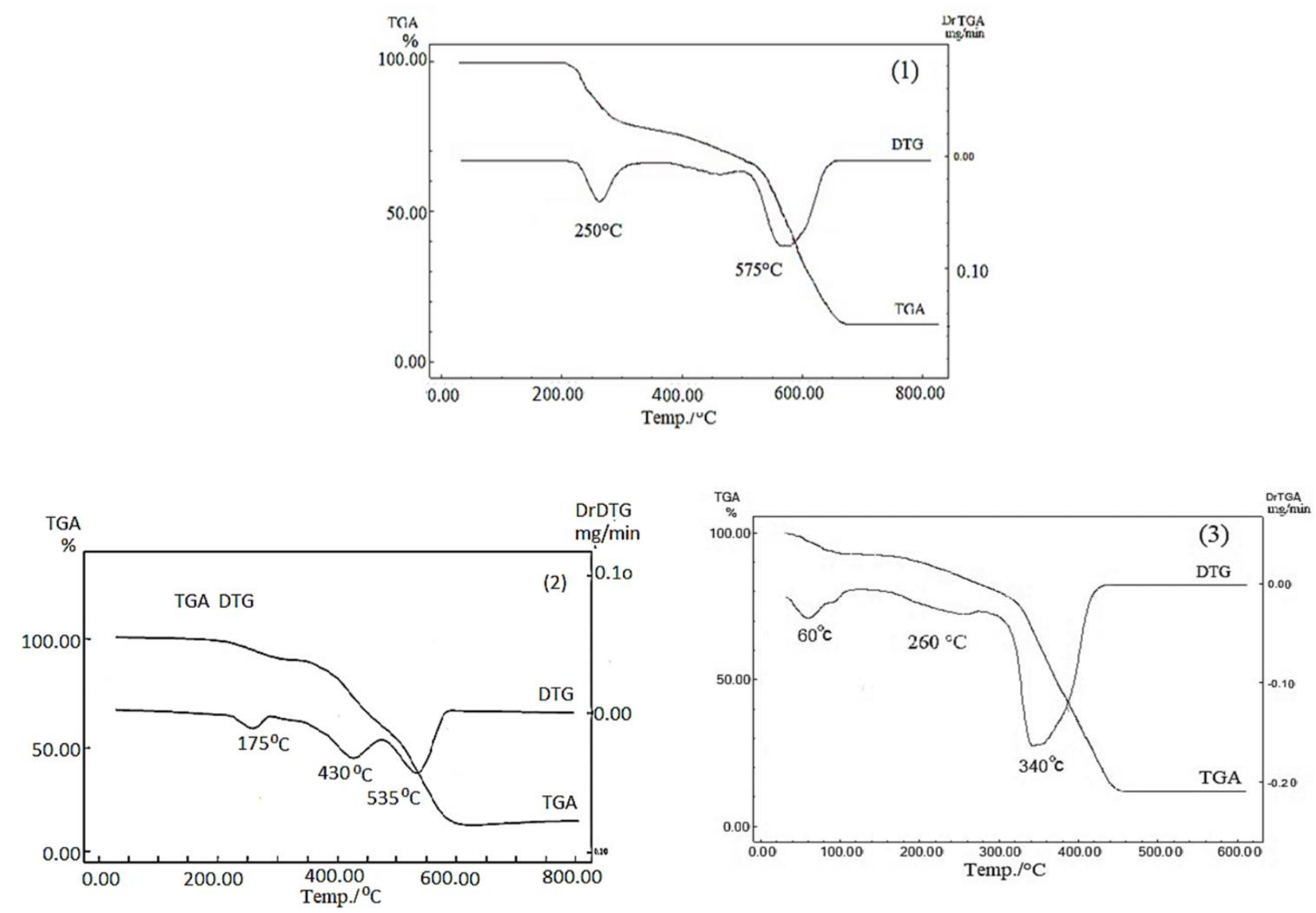

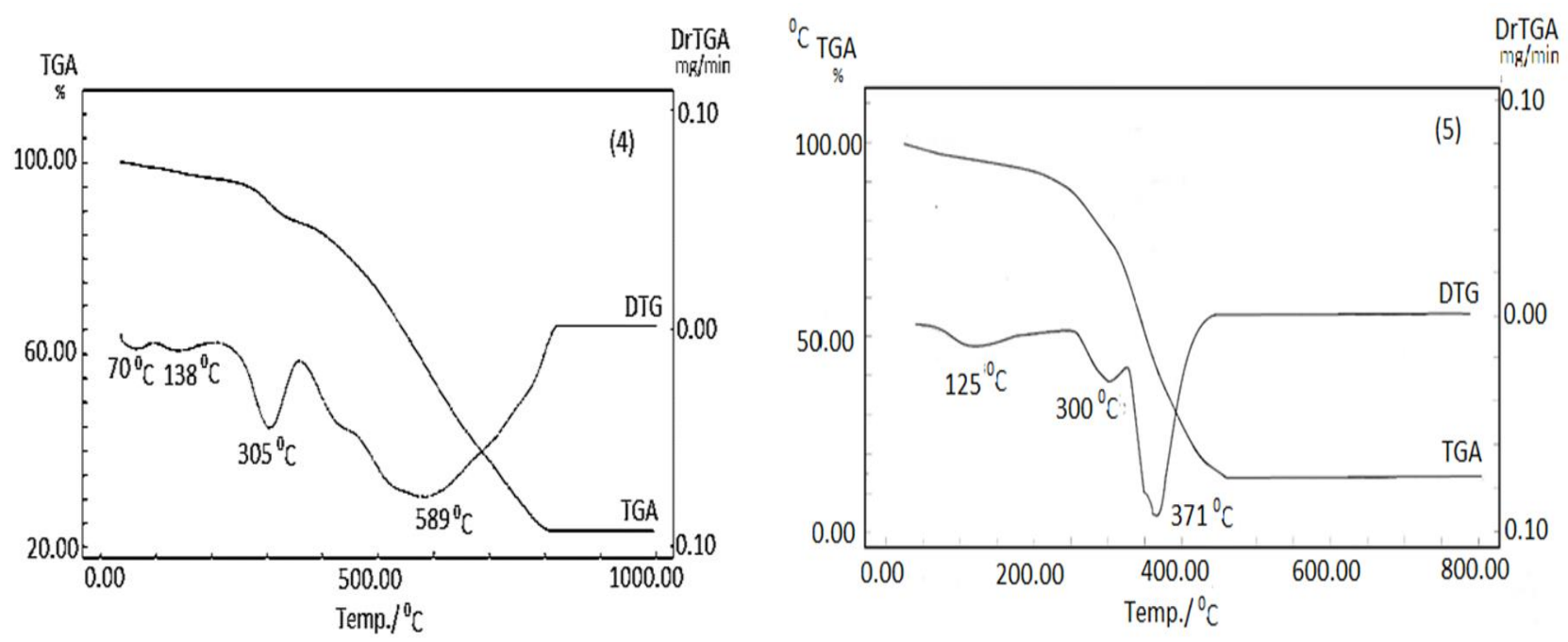

Figure 1; TG/DTG curve of the complexes (1-5)

\subsubsection{Nickel (II) Chelates}

TG curves of $\left[\mathrm{Ni}(\mathrm{L})\left(\mathrm{H}_{2} \mathrm{O}\right)_{4}\right] \mathrm{Cl}_{2} \cdot 2 \mathrm{H}_{2} \mathrm{O}(\mathbf{4})$ and $\left[\mathrm{Ni}(\mathrm{L})\left(\mathrm{H}_{2} \mathrm{O}\right)_{2}(\mathrm{OH})(\mathrm{OAC})\right] 2 \mathrm{H}_{2} \mathrm{O}$ (5) complexes exhibit two stages of decomposition. The first stage dehydration within the temperature range of $30-180^{\circ} \mathrm{C}$ with weight loss(Cal. \% 6.16 F. 5.55) and (Cal.\% 6.51; F.6.54) related to the evolution of two and three hydrated water molecules, that associated with two DTG peaks at $70,138^{\circ} \mathrm{C}$ and one peak at $125^{\circ} \mathrm{C}$, respectively. The second stage in the temperature range of $230-1000$ and $200-650^{\circ} \mathrm{C}$ attribute to complete decomposition of complexes (4) and (5), (Cal. \% 74.83 F. 75.41) and (Cal.\% 79.99; F. 80.26), respectively. DTG curve for $(\mathbf{4 , 5})$ complexes showed peaks at $305,589^{\circ} \mathrm{C}$ and $300,371^{\circ} \mathrm{C}$ leaving $\mathrm{NiO}$ for complexes $(\mathbf{4 , 5})$ as a final product (Table 4). It is worth to note that for residue of complex (4), slight higher value percentage found indicating that the residue is contaminated with some carbon atoms (Fig1)[34, 39].
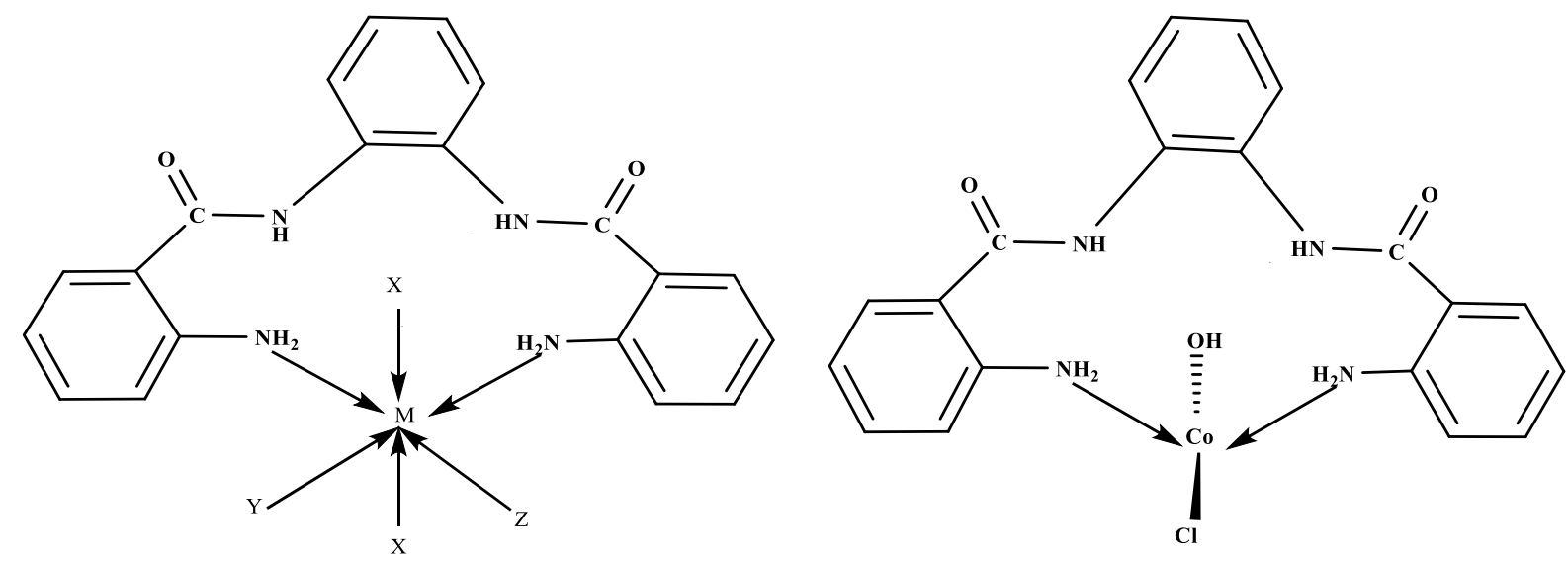

(1) 


\begin{tabular}{llllll}
\hline No & $\mathbf{M}(\mathrm{II})$ & $\mathbf{X}$ & $\mathbf{Y}$ & $\mathbf{z}$ & $\mathbf{n}$ \\
\hline (2) & $\mathrm{CO}{ }^{y}$ & $\mathrm{H} 2 \mathrm{O}$ & $\mathrm{Cl}$ & $\mathrm{Cl}$ & - \\
(3) & $\mathrm{Co}$ & $\mathrm{H}_{2} \mathrm{O}$ & $\mathrm{OH}$ & $(\mathrm{OAC})$ & $6 \mathrm{H}_{2} \mathrm{O}$ \\
(4) & $\mathrm{Ni}$ & $\mathrm{H}_{2} \mathrm{O}$ & $\mathrm{H}_{2} \mathrm{O}$ & $\mathrm{H}_{2} \mathrm{O}$ & $\mathrm{Cl}_{2} .2 \mathrm{H}_{2} \mathrm{O}$ \\
(5) & $\mathrm{Ni}$ & $\mathrm{H}_{2} \mathrm{O}$ & $\mathrm{OH}$ & $(\mathrm{OAC})$ & $3 \mathrm{H}_{2} \mathrm{O}$ \\
\hline
\end{tabular}

Figure 2: suggested structure of the obtained complexes (1-5)

Based on the above analytical, spectral, and thermal studies, it is confirmed that the synthesized $\mathrm{Co}(\mathrm{II})$ and $\mathrm{Ni}$ (II) complexes (2-5) have an octahedral geometry, while $\mathrm{Co}$ (II) complex (1) have tetrahedral geometry. The suggested structure of the obtained complexes are given in figure 2 .

\section{Antimicrobial Activity}

\subsection{Antibacterial Activity}

The free ligand and its metal complexes were tested against bacterial species by measuring the bacteriostatic diameter. The results were listed in table 5 and Figure 3. The observed data summarized as follow:

1) Generally, most tested complexes show more activity and the ligand do not have any activity against S.aureus and E.coli under identical experimental conditions.

2) The complexes have different activities for both two concentrations 10 and $20 \mathrm{mg} / \mathrm{mL}$ with inhibition range of 8-14 $\mathrm{mm}$ against S.aureus and E.coli.

3) All complexes possess high activity against S.aureus at higher concentration ( $20 \mathrm{mg} / \mathrm{mL})$ more than at low concentration (10 mg/mL) except for complex (3) that have no activity with low concentration.

4) For $(10 \mathrm{mg} / \mathrm{mL})$ concentration, the complexes $(\mathbf{1}, \mathbf{2})$ have more activity than that measured at $(20 \mathrm{mg} / \mathrm{mL})$ concentration against E.coli.

5) All these activity values are compared with that of positive control of commercial, broad spectrum and the most available drug Ampicillin, $22 \mathrm{~mm}$ and $26 \mathrm{~mm}$ with $10 \mathrm{mg} / \mathrm{mL}$ and $20 \mathrm{mg} / \mathrm{mL}$ respectively.

Antibacterial activity of metal complexes was affected by many factors, such as the chelate effect of the ligand, the nature of the donner atoms/metal ion/counter ions that neutralize the complex, the total charge on the 
complex ion and the geometric structure of the complex. All these factors play important role in the increase of the lipophilicity of the central metal atom which increase the hydrophobic character and liposolubility of the complex that facilitate the permeation through the lipid layer of the bacterial membrane [34, 42]. Due to the complexity of biological system, it is difficult to estimate exact mechanism for such activities. The higher activity of complexes could be explained according to Tweedy and chelation theory, Chelation decreases the polarity of the metal ion due to partial sharing of positive charge with donner groups and delocalized electrons of chelate ring system formed during coordination [42-44].

\subsection{Antifungal Activity}

Candida albicans was used as fungal strain by measuring the fungi static diameter with the free ligand and metal complexes. The result were listed in table $\mathbf{5}$ and figure4.

1. Candida albicans was affected by the free ligand like other complexes $(\mathbf{3}, \mathbf{4 , 5})$ with inhibition rang of 8-14 $\mathrm{mm}$ compared with the positive control drug used for both two concentration Fluconazole which gave inhibition values 30 and $26 \mathrm{~mm}$ at 10 and $20 \mathrm{mg} / \mathrm{mL}$ concentration, respectively.

2. Complexes (1) have no activity with both concentrations used. Complex (2) has no activity with the concentration of $20 \mathrm{mg} / \mathrm{mL}$. It was clear that the fungal activity may be affected with the nature of each metal ion.

3. The complexes have different activities for both two concentrations 10 and $20 \mathrm{mg} / \mathrm{mL}$ with inhibition range of 8-14 mm.

A fact that can be explained by Tweedy's chelation theory It is believed that other factors, such as liposolubility, dipole moment, conductivity are influenced by metal ion, geometry, number and type of metal ions, and counter ions. Furthermore, moieties, as carbonyl group present in these compounds, may be possible reasons for their remarkable antibacterial activities. The result may be explained due to the presence of chlorine ion in some complexes, which may be combined with membrane proteins and enzymes. The increase of antifungal activities may be due to formation of hypochlorous acid that decompose to $\mathrm{HCl}$ and $\mathrm{O}_{2}$ which destroy the cellular components and the microbes $[34,43]$. Compounds with noticeable activity may be considered a start point for development of some new antimicrobial agents $[44,45]$.

\begin{tabular}{|c|c|c|c|c|c|c|c|}
\hline \multirow[t]{3}{*}{ No } & \multirow[t]{3}{*}{ Compound } & \multicolumn{4}{|l|}{ Bacteria. } & \multirow{2}{*}{\multicolumn{2}{|c|}{$\begin{array}{l}\text { Fungi. } \\
\text { Candida albicans }\end{array}$}} \\
\hline & & \multicolumn{2}{|c|}{ Staphylococcus aureus } & \multicolumn{2}{|c|}{ Escherichia coli } & & \\
\hline & & $10 \mathrm{mg} / \mathrm{mL}$ & $20 \mathrm{mg} / \mathrm{mL}$ & $10 \mathrm{mg} / \mathrm{mL}$ & $20 \mathrm{mg} / \mathrm{mL}$ & $10 \mathrm{mg} / \mathrm{mL}$ & $20 \mathrm{mg} / \mathrm{mL}$ \\
\hline & Ampicillin & 22 & 26 & 14 & 18 & ---- & ---- \\
\hline & Fluconazole & ---- & ---- & ---- & ---- & 26 & 30 \\
\hline & Ligand & ---- & ---- & ---- & ---- & 9 & 10 \\
\hline 1 & {$[\mathrm{Co}(\mathrm{L}) \mathrm{Cl}(\mathrm{OH})]^{x}$} & 8 & 8 & 12 & 9 & ---- & ---- \\
\hline 2 & {$\left[\mathrm{Co}(\mathrm{L})\left(\mathrm{Cl}_{2}\right)\left(\mathrm{H}_{2} \mathrm{O}\right)_{2}\right]^{y}$} & 10 & 11 & 12 & ---- & 8 & ---- \\
\hline 3 & {$\left[\mathrm{Co}(\mathrm{L})\left(\mathrm{H}_{2} \mathrm{O}\right)_{2}(\mathrm{OH})(\mathrm{OAc})\right] .6 \mathrm{H}_{2} \mathrm{O}$} & ---- & 14 & 11 & 14 & 11 & 10 \\
\hline 4 & {$\left[\mathrm{Ni}(\mathrm{L})\left(\mathrm{H}_{2} \mathrm{O}\right)_{4}\right] \cdot \mathrm{Cl}_{2} \cdot 2 \mathrm{H}_{2} \mathrm{O}$} & 10 & 12 & 11 & ---- & 10 & 9 \\
\hline 5 & {$\left[\mathrm{Ni}(\mathrm{L})\left(\mathrm{H}_{2} \mathrm{O}\right)_{2}(\mathrm{OH})(\mathrm{OAc})\right] \cdot 2 \mathrm{H}_{2} \mathrm{O}$} & 13 & 12 & ---- & 8 & 11 & 14 \\
\hline
\end{tabular}

${ }^{*} x$; synthesis ith acetone as solvent; $y$, synthesis with ethanol as solvent.

Table 5: Antibacterial and antifungal activities of ligand and its complexes at concentration of $(10,20 \mathrm{mg} / \mathrm{mL})$. 


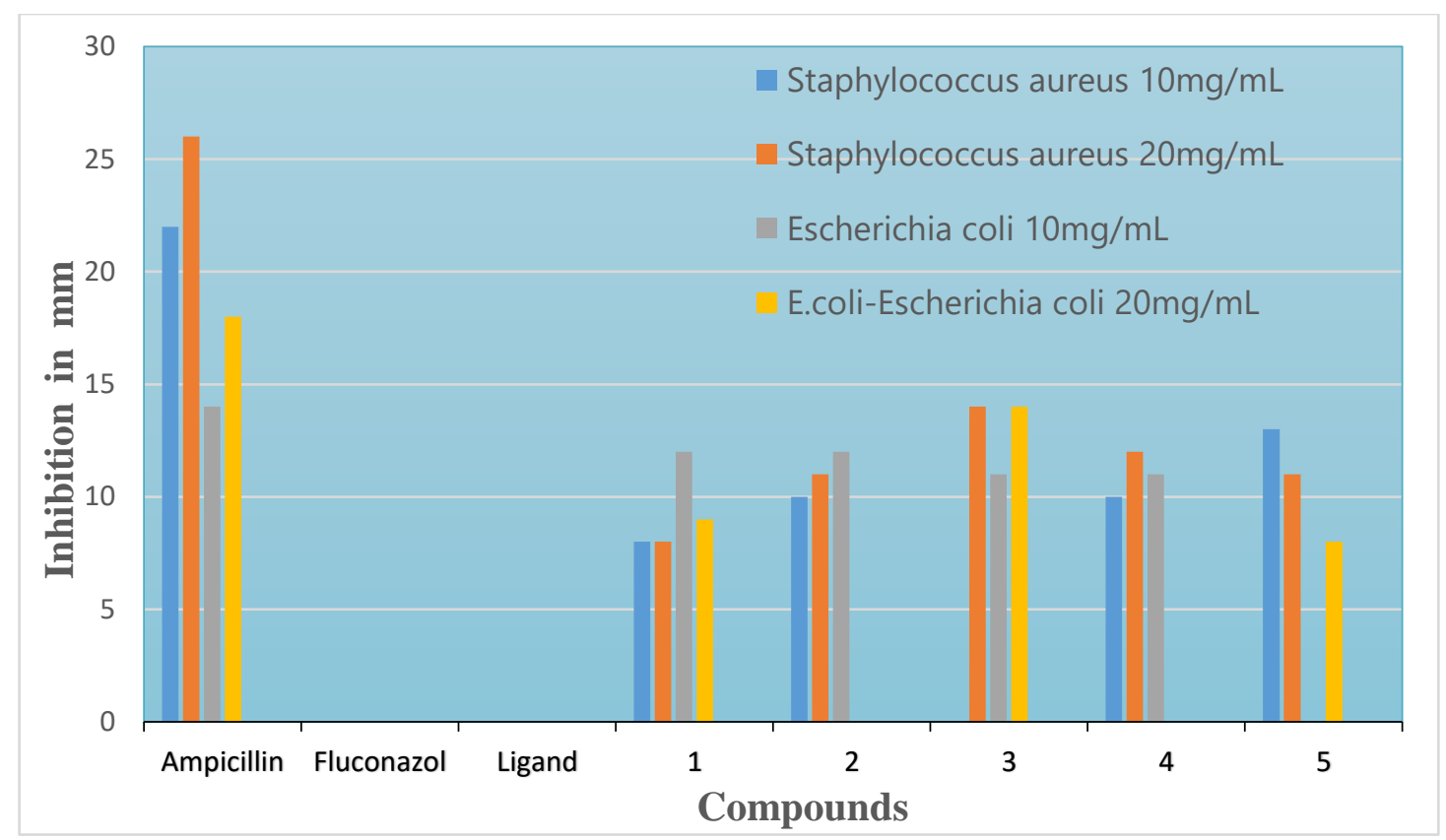

Figure 3: Antibacterial activity for tested compounds.

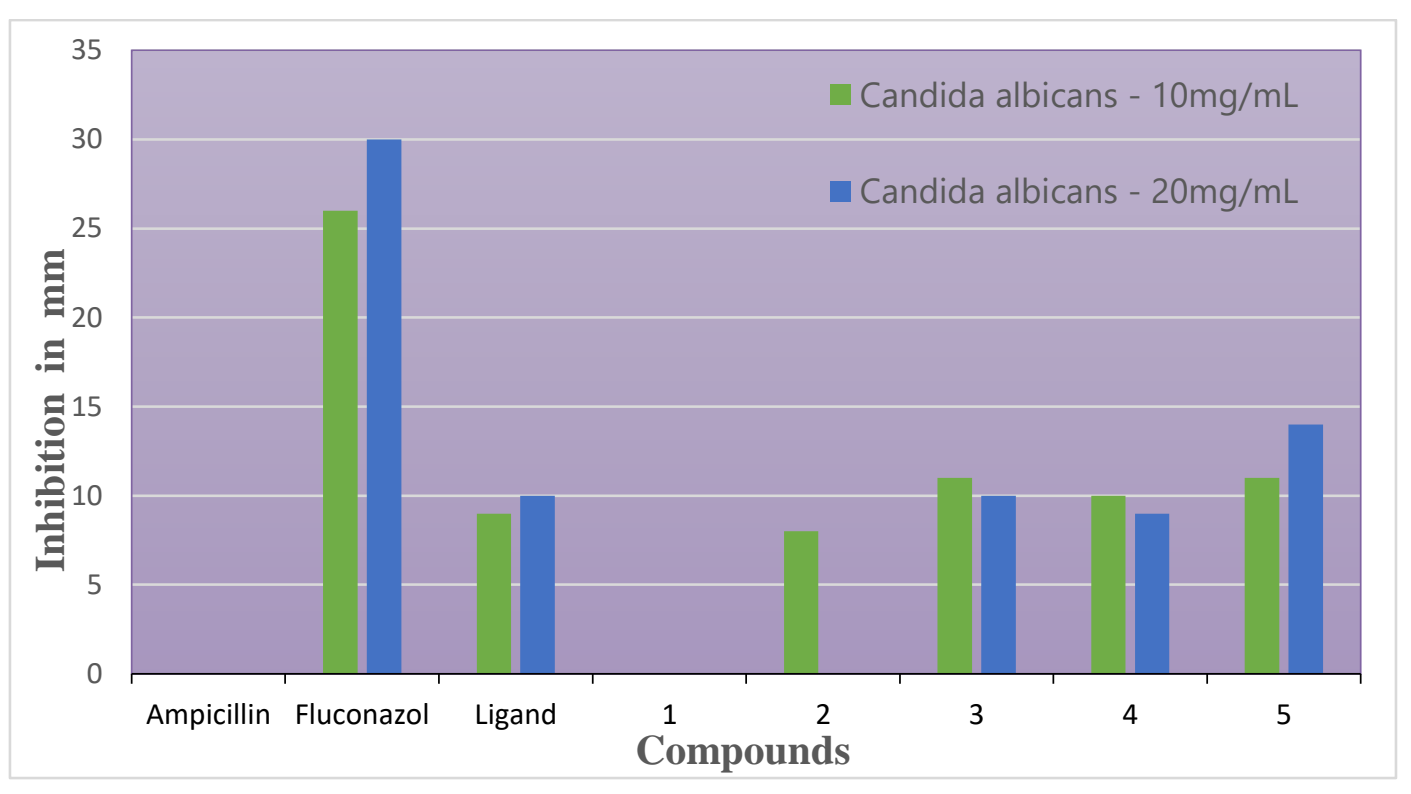

Figure 4: Antifungal activity for tested compounds.

\section{Conclusion}

Herein we report the synthesis and characterization of the new metal complexes of $\mathrm{Co}$ (II) and Ni(II). The obtained analytical and physiochemical information confirm composition and structure mode of the newly prepared compounds. The results of this work may be briefly summarized in the following points:

1) The ligand behaved as bidentate one through nitrogen atom of amine.

2) IR spectra, UV-Vis and magnetic moment indicated that the complexes are mononuclear, octahedral geometry except complex (1) adopted in tetrahedral geometry. 
3) The molar conductance values in DMF showed non electrolytic nature for all metal complexes except complex (4) of nickel (II) chloride is 1:2 electrolyte.

4) The ligand and its prepared complexes were invitro screened against Gram-positive and Gram-negative bacteria as Staphylococcus aureus and Escherichia coli respectively, and fungi as Candida albicans. The data showed that most prepared complexes revealed variable activities higher than the ligand towards the studied bacterial and fungal organisms.

5) Compounds with noticeable activity may be considered a start point for development of some new antimicrobial and antifungal agents.

Conflicts of Interest: There are no conflicts.

Funding Statement: There are no Funding Statements.

Acknowledgments: No Acknowledgments.

\section{References}

1. Ebner, T., O. Shebl, R.B. Mayer, M. Moser, W. Costamoling, and P. Oppelt, Healthy live birth using theophylline in a case of retrograde ejaculation and absolute asthenozoospermia. Fertility and sterility, 2014. 101(2): p. 340-343.

2. Shebl, M., S.M. Khalil, and F.S. Al-Gohani, Preparation, spectral characterization and antimicrobial activity of binary and ternary Fe (III), Co (II), Ni (II), CU (II), Zn (II), Ce (III) and UO2 (VI) complexes of a thiocarbohydrazone ligand. Journal of Molecular Structure, 2010. 980(1-3): p. 78-87.

3. Swamy, S.J., S. Jyothi, P. Someshwar, K. Shashank, and G.R. Rao, Synthesis and Structural analysis of N4donar ligands and their complexes with some bivalent transition metal ions. Journal of Applicable Chemistry, 2012. 1(2): p. 218-231.

4. Fache, F., E. Schulz, M.L. Tommasino, and M. Lemaire, Nitrogen-containing ligands for asymmetric homogeneous and heterogeneous catalysis. Chemical Reviews, 2000. 100(6): p. 2159-2232.

5. Alcón, M., M. Iglesias, and F. Sánchez, Copper and manganese complexes with C 2-multitopic ligands. Xray crystal structure of [Cu (N, N'-bis [(S)-prolyl] phenylenediamine) H 2 O]. Catalytic properties. Inorganica chimica acta, 2002. 333(1): p. 83-92.

6. El-Boraey, H.A., Coordination behavior of tetraaza [N4] ligand towards $\mathrm{Co}$ (II), $\mathrm{Ni}$ (II), Cu (II), Cu (I) and Pd (II) complexes: synthesis, spectroscopic characterization and anticancer activity. Spectrochimica Acta Part A: Molecular and Biomolecular Spectroscopy, 2012. 97: p. 255-262.

7. Tyagi, P., S. Chandra, B. Saraswat, and D. Sharma, Design, spectral characterization, DFT and biological studies of transition metal complexes of Schiff base derived from 2-aminobenzamide, pyrrole and furan aldehyde. Spectrochimica Acta Part A: Molecular and Biomolecular Spectroscopy, 2015. 143: p. 1-11.

8. Tyagi, P., S. Chandra, and B. Saraswat, Ni (II) and Zn (II) complexes of 2-((thiophen-2-ylmethylene) amino) benzamide: Synthesis, spectroscopic characterization, thermal, DFT and anticancer activities. Spectrochimica Acta Part A: Molecular and Biomolecular Spectroscopy, 2015. 134: p. 200-209.

9. Dharmaraja, J., P. Subbaraj, T. Esakkidurai, and S. Shobana, Coordination behavior and bio-potent aspects of $\mathrm{Ni} \mathrm{(II)} \mathrm{with} \mathrm{2-aminobenzamide} \mathrm{and} \mathrm{some} \mathrm{amino} \mathrm{acid} \mathrm{mixed} \mathrm{ligands-Part} \mathrm{II:} \mathrm{Synthesis,} \mathrm{spectral,}$ 
morphological, pharmacological and DNA interaction studies. Spectrochimica Acta Part A: Molecular and Biomolecular Spectroscopy, 2014. 132: p. 604-614.

10. Kang, D., J. Seo, S.Y. Lee, J.Y. Lee, K.S. Choi, and S.S. Lee, First dicadmium (II) complex of tripodal amide ligand with one edge-sharing monocapped octahedral geometry. Inorganic Chemistry Communications, 2007. 10(12): p. 1425-1428.

11. Noyori, R. and R. Noyori, Asymmetric catalysis in organic synthesis. 1994.

12. El-Asmy, A.A., A. Al-Abdeen, W.A. El-Maaty, and M. Mostafa, Synthesis and spectroscopic studies of 2, 5hexanedione bis (isonicotinylhydrazone) and its first raw transition metal complexes. Spectrochimica Acta Part A: Molecular and Biomolecular Spectroscopy, 2010. 75(5): p. 1516-1522.

13. Lee, R.F., S. Theiner, A. Meibom, G. Koellensperger, B.K. Keppler, and P.J. Dyson, Application of imaging mass spectrometry approaches to facilitate metal-based anticancer drug research. Metallomics, 2017. 9(4): p. 365-381.

14. El-Boraey, H.A. and A.I. Mansour, Synthesis, spectral and gamma ray irradiation studies on metal complexes of N, N'-naphthalene-1, 8-diylbis (2-aminobenzamide). Inorganic and Nano-Metal Chemistry, 2017(just-accepted): p. 00-00.

15. Raman, N., Y.P. Raja, and A. Kulandaisamy. Synthesis and characterization of Cu (II), Ni (II), Mn (II), Zn (II) and VO (II) Schiff base complexes derived from o-phenylenediamine and acetoacetanilide. in PROCEEDINGS-INDIAN ACADEMY OF SCIENCES CHEMICAL SCIENCES. 2001. Indian Academy of Sciences; 1999.

16. Tyagi, P., M. Tyagi, S. Agrawal, S. Chandra, H. Ojha, and M. Pathak, Synthesis, characterization of 1, 2, 4triazole Schiff base derived 3d-metal complexes: Induces cytotoxicity in HepG2, MCF-7 cell line, BSA binding fluorescence and DFT study. Spectrochimica Acta Part A: Molecular and Biomolecular Spectroscopy, 2017. 171: p. 246-257.

17. Bassett, J., J. Bassett, R. Denney, G. Jeffery, and J. Mentham, Vogel's Textbook of Quantitative Inorganic Analysis: Including Elementry Instrumental Analysis. 1985: Longman ELBS.

18. West, T.S., Complexometry with EDTA and related reagents. 1969: BDH Chemicals Ltd.

19. Swamy, S., K. Suresh, P. Someshwar, and D. Nagaraju, Synthesis of novel Schiff's bases containing pyridine rings. Synthetic communications, 2004. 34(10): p. 1847-1853.

20. Bauer, A., W. Kirby, J.C. Sherris, and M. Turck, Antibiotic susceptibility testing by a standardized single disk method. American journal of clinical pathology, 1966. 45(4): p. 493.

21. PANKUCH, G.A., M.R. JACOBS, and P.C. APPELBAUM, Activity of CP 99, 219 compared with DU-6859a, ciprofloxacin, ofloxacin, levofloxacin, lomefloxacin, tosufloxacin, sparfloxacin and grepaloxacin against penicillin-susceptible and-resistant pneumococci. Journal of Antimicrobial Chemotherapy, 1995. 35(1): $p$. 230-232.

22. Ostrosky-Zeichner, L., J.H. Rex, M.A. Pfaller, D.J. Diekema, B.D. Alexander, D. Andes, S.D. Brown, V. Chaturvedi, M.A. Ghannoum, and C.C. Knapp, Rationale for reading fluconazole MICs at 24 hours rather than 48 hours when testing Candida spp. by the CLSI M27-A2 standard method. Antimicrobial agents and chemotherapy, 2008. 52(11): p. 4175-4177. 
23. Yousif, E., A. Majeed, K. Al-Sammarrae, N. Salih, J. Salimon, and B. Abdullah, Metal complexes of Schiff base: preparation, characterization and antibacterial activity. Arabian Journal of Chemistry, 2017. 10: $p$. S1639-S1644.

24. Dhayabaran, V.V. and T.D. Prakash, Spectral And Theoretical Studies On The Impact Of M (II) Complexes Of Amino Acid-Nucleobase Hybrid Ligand On BSA Binding: An Approach Towards New Metallodrugs. 2017.

25. Gull, P., S.A. AL-Thabaiti, and A.A. Hashmi, Design, Characterization and antimicrobial activity of Cu (II), Co (II) and Zn (II) complexes with Schiff base from 1, 2-diphenylethane-1, 2-dione and N-(1-Naphthyl) ethylenediamine. Int. J. of Multidisciplinary and Current research, 2014.

26. Swamy, S., B. Veerapratap, D. Nagaraju, K. Suresh, and P. Someshwar, Non-template synthesis of 'N4'diand tetra-amide macrocylic ligands with variable ring sizes. Tetrahedron, 2003. 59(50): p. 10093-10096.

27. El-Boraey, H.A. and A.A.S. El-Din, Transition metal complexes of a new 15-membered [N5] pentaazamacrocyclic ligand with their spectral and anticancer studies. Spectrochimica Acta Part A: Molecular and Biomolecular Spectroscopy, 2014. 132: p. 663-671.

28. El-Boraey, H.A. and O.A. El-Gammal, New 15-membered tetraaza (N 4) macrocyclic ligand and its transition metal complexes: spectral, magnetic, thermal and anticancer activity. Spectrochimica Acta Part A: Molecular and Biomolecular Spectroscopy, 2015. 138: p. 553-562.

29. Ayad, M.I. and H.A. El-Boraey, Characterization, thermal and electrical conductivity of some transition metal adducts. International Journal of ChemTech Research, 2014. 6(1): p. 266-275.

30. El-Boraey, H.A., S.M. Emam, D.A. Tolan, and A.M. El-Nahas, Structural studies and anticancer activity of a novel (N6O4) macrocyclic ligand and its $\mathrm{Cu}$ (II) complexes. Spectrochimica Acta Part A: Molecular and Biomolecular Spectroscopy, 2011. 78(1): p. 360-370.

31. Chaudhary, A. and R. Singh, Txicological Aspects of Newly Designed Macrocyclic Complexes of Iron (II). Metal-based drugs, 2002. 8(6): p. 315-321.

32. Angelusiu, M.V., G.L. Almajan, T. Rosu, M. Negoiu, E.-R. Almajan, and J. Roy, Copper (II) and uranyl (II) complexes with acylthiosemicarbazide: Synthesis, characterization, antibacterial activity and effects on the growth of promyelocytic leukemia cells HL-60. European journal of medicinal chemistry, 2009. 44(8): p. 3323-3329.

33. Joseyphus, R.S. and M.S. Nair, Synthesis, characterization and biological studies of some Co (II), Ni (II) and $\mathrm{Cu}$ (II) complexes derived from indole-3-carboxaldehyde and glycylglycine as Schiff base ligand. Arabian Journal of Chemistry, 2010. 3(4): p. 195-204.

34. Abd El-Halim, H., G.G. Mohamed, and M.N. Anwar, Antimicrobial and anticancer activities of Schiff base ligand and its transition metal mixed ligand complexes with heterocyclic base. Applied Organometallic Chemistry, 2018. 32(1).

35. Chandra, S. and U. Kumar, Spectral and magnetic studies on manganese (II), cobalt (II) and nickel (II) complexes with Schiff bases. Spectrochimica Acta Part A: Molecular and Biomolecular Spectroscopy, 2005. 61(1-2): p. 219-224.

36. Shakir, M., A. Abbasi, M. Azam, and A.U. Khan, Synthesis, spectroscopic studies and crystal structure of the Schiff base ligand $L$ derived from condensation of 2-thiophenecarboxaldehyde and 3, 3'diaminobenzidine and its complexes with $\mathrm{Co}$ (II), $\mathrm{Ni}$ (II), $\mathrm{CU}$ (II), $\mathrm{Cd}$ (II) and $\mathrm{Hg}$ (II): Comparative DNA binding 
studies of L and its $\mathrm{Co}$ (II), Ni (II) and Cu (II) complexes. Spectrochimica Acta Part A: Molecular and Biomolecular Spectroscopy, 2011. 79(5): p. 1866-1875.

37. Omar, M. and G.G. Mohamed, Potentiometric, spectroscopic and thermal studies on the metal chelates of 1-(2-thiazolylazo)-2-naphthalenol. Spectrochimica Acta Part A: Molecular and Biomolecular Spectroscopy, 2005. 61(5): p. 929-936.

38. Jayashri, T. and K. Viji, Spectral, X-ray diffraction, surface morphological and thermal studies of gammairradiated potassium bis (oxalato) zincate (II) dihydrate. Radiation Effects and Defects in Solids, 2018: p. 1-10.

39. Shebl, M., Synthesis, spectroscopic characterization and antimicrobial activity of binuclear metal complexes of a new asymmetrical Schiff base ligand: DNA binding affinity of copper (II) complexes. Spectrochimica Acta Part A: Molecular and Biomolecular Spectroscopy, 2014. 117: p. 127-137.

40. Hatakeyama, T. and Z. Liu, Thermal analysis curves of minerals. Handbook of thermal analysis. Chichester, England: Wiley, 1998: p. 247-336.

41. Al-Shihri, A.S., Synthesis, characterization and thermal analysis of some new transition metal complexes of a polydentate Schiff base. Spectrochimica Acta Part A: Molecular and Biomolecular Spectroscopy, 2004. 60(5): p. 1189-1192.

42. Gayathri, N. and M. Suresh, Synthesis and spectral characterization of oxovanadium complexes derived from benzoin, O-phenylenediamine and ethylenediamine and their antibacterial activities. Int. J. Curr. Res. Chem. Pharm. Sci, 2017. 4(1): p. 12-19.

43. Abdel-Rahman, L.H., A.M. Abu-Dief, H. Moustafa, and S.K. Hamdan, Ni (II) and Cu (II) complexes with ONNO asymmetric tetradentate Schiff base ligand: synthesis, spectroscopic characterization, theoretical calculations, DNA interaction and antimicrobial studies. Applied Organometallic Chemistry, 2017. 31(2).

44. El-Boraey, H.A. and M.A. El-Salamony, Transition Metal Complexes with Polydentate Ligand: Synthesis, Characterization, 3D Molecular Modelling, Anticancer, Antioxidant and Antibacterial Evaluation. Journal of Inorganic and Organometallic Polymers and Materials, 2019. 29(3): p. 684-700.

45. Masoud, M.S., S.S. Hagagg, A.E. Ali, and N.M. Nasr, Synthesis and spectroscopic characterization of gallic acid and some of its azo complexes. Journal of Molecular Structure, 2012. 1014: p. 17-25. 